Journal Archives of Environmental Contamination and Toxicology

April, 2007 : Issue Volume 52, Number 3: 418-430

http://dx.doi.org/10.1007/s00244-005-0225-2

(c)2007 Springer Science+Business Media
Archimer, archive institutionnelle de l'Ifremer http://www.ifremer.fr/docelec/

The original publication is available at http://www.springerlink.com

\title{
Trace Elements in Three Marine Birds Breeding on Reunion Island (Western Indian Ocean): Part 1-Factors Influencing Their Bioaccumulation
}

\author{
Jessica Kojadinovic ${ }^{123 *}$, Matthieu Le Corre ${ }^{1}$, Richard P. Cosson ${ }^{2}$ \& Paco Bustamante ${ }^{3}$ \\ ${ }^{1}$ Université de La Réunion, ECOMAR, 15 avenue René Cassin,Saint Denis de La Réunion, F-97715 \\ France \\ 2 Université de Nantes, EMI, EA 2663, BP 92208, Nantes cedex 3, F-44322 France \\ ${ }^{3}$ CRELA, UMR 6217, CNRS-IFREMER-Université de La Rochelle, 22 avenue Michel Crépeau, La \\ Rochelle, F-17042 France
}

*: Corresponding author: Jessica.Kojadinovic@univ-nantes.fr ; Tel : +(33)2.51.12.56.91; FAX : (33)2.51.12.56.58

\begin{abstract}
:
This work aimed to use seabirds as bioindicators of trace element levels in the tropical waters and food webs of the Western Indian Ocean. The accumulation patterns of selected toxic $(\mathrm{Cd}$ and $\mathrm{Hg}$ ) and essential (Cu, Fe, Mn, Se, and Zn) elements were determined in liver, kidney, and pectoral muscle of 162 marine birds belonging to 3 species collected in Reunion Island between 2002 and 2004. These pelagic seabirds belong to the following species: Barau's Petrel (Pterodroma baraui), Audubon's Shearwater (Puffinus Iherminieri bailloni), and White-Tailed Tropicbird (Phaethon lepturus). Hg levels were also measured in breast feathers. Highest mean kidney $\mathrm{Cd}$ and liver $\mathrm{Hg}$ levels (respectively, $27.79 \pm 13.78 \mu \mathrm{g} . \mathrm{g}^{-1}$ dry weight $(\mathrm{dw})$ and $24.31 \pm 14.13 \mu \mathrm{g} \cdot \mathrm{g}^{-1} \mathrm{dw}$ ) were found in the squid-eating Barau's Petrel. Barau's Petrel feather Hg levels fell in the range of 0.6 to $2.7 \mu \mathrm{g} \cdot \mathrm{g}^{-1} \mathrm{dw}$ previously reported for other petrels and shearwaters. The values of the other elements were also in the same range as those previously reported in the published literature concerning related seabirds, although Se and $\mathrm{Zn}$ burdens in the Reunion birds were among the highest values. Levels of $\mathrm{Zn}$, Fe, and, to a lesser extent, $\mathrm{Cu}$ appeared to be regulated in seabird tissues. Uptake and pathways of metabolism and storage seemed to be similar for the five essential elements. The reproductive status of the bird did not seem to affect element levels, which, moreover, were not significantly different between male and female birds. However, trace elements in sampled birds varied according to the tissue considered, the age of the animal, and its species. Diet was seemingly a major influencing factor. Health status also appeared to have an impact on element levels.
\end{abstract}

Keywords: Metals, Tissue distribution, Feathers, Tropical seabirds, Contamination. 


\section{Introduction}

Contaminants such as metals and metalloids reach oceans through natural erosion, geochemical cycles and human activity. Once in the marine environment, they can enter the food web where bioaccumulation and/or biomagnification can occur. Top-predators such as marine birds, are particularly exposed to high levels of these trace elements through their food (Bearhop et al. 2000). Because of their trophic position and bioaccumulation capacities, seabirds are often used as bioindicators of elemental levels in the marine environment (Walsh 1990, Furness et al. 1993, Monteiro and Furness 1995, Gray 2002).

In spite of the great variety and number of seabirds present in the southern hemisphere, most studies have been carried out on species inhabiting the northern hemisphere. The few studies conducted on trace elements in the southern hemisphere focused on temperate and subantartic species, i.e. from Chile (Ochoa-Acuna et al. 2002), New Zealand (Fiona et al. 1999), Gough island (Muirhead and Furness 1988), the Kerguelen islands (Bocher et al. 2003) and the Antarctic Ocean (Szefer et al. 1993, Ancora et al. 2002, Gonzalez-Solis et al. 2002). The tropical zone of the Indian Ocean has, up to the present day, received very little attention from researchers in reference to biocenosis trace element contamination. Overall, tropical waters are less monitored than marine environments from temperate and polar regions, more particularly southern tropical oceans which are often considered as less polluted than the northern ones (Fiona et al. 1999). However, the study of unpolluted sites can be of great interest, allowing an estimation of the "background" levels of contaminants to be made and can thus be used as a reference in space and time.

Through the study of trace element levels in marine birds from Reunion Island, this paper presents novel data on elemental contamination in seabirds of the western part of the tropical Indian Ocean. This work focuses on three seabird species chosen for their contrasting dietary ecology. Barau's Petrel (Pterodroma baraui) is a pelagic bird which feeds almost exclusively on cephalopods. Aububon's Shearwater (Puffinus lherminieri bailloni) which forages closer to the coast feeds as much on cephalopods as it does on fish. Finally, the White-tailed Tropicbird (Phaethon lepturus) also forages over oceanic waters but at intermediate distances from the island compared to the other two species, and is less specialized on squid than Barau's Petrel.

In the organism, elements are transported in the blood, deposited in various tissues and excreted or stored. Understanding the global patterns of accumulation and excretion is useful in evaluating the sources of contamination and the potential risks to an individual species. In the first part of this article, we examine the levels of two non-essential elements (cadmium and mercury) and five essential elements (copper, iron, manganese, selenium and zinc) in liver, kidney and muscle, as well as mercury levels in feathers. We also studied the factors influencing the elemental burdens and the correlations among these trace elements' levels.

\section{Materials and methods}

\subsection{Study site and species}

The seabirds used in this study originated from colonies on Reunion Island $\left(21^{\circ} 7^{\prime} S, 55^{\circ} 33^{\prime} E\right)$, a French territory $\left(2512 \mathrm{~km}^{2}\right)$ located $700 \mathrm{~km}$ east of Madagascar in the Western Indian 


\section{Ocean.}

Barau's Petrel, described for the first time in 1963 (Jouanin 1963), is endemic to Reunion Island, where its population is estimated at 4000 to 6500 pairs (Le Corre et al. 2001b). This pelagic bird is present on the island from September (courtship and mating) to April (fledglings' first flight) (Bretagnolle and Attié 1991). The eggs are laid in November. During its reproduction season, Barau's Petrel scatters to feed in the tropical and sub-tropical waters as far as several hundred kilometers south of Reunion Island. Its diet consists of 98\% cephalopods (Stenoteuthis oualaniensis and Taonius sp., given as percentage of the total number of prey items) and $2 \%$ fish (Gigan \& Lebon, pers. comm.). From March to September, Barau's Petrel leaves Reunion waters and migrates towards the north and the east of the Indian Ocean (Barré et al. 1996, Stahl and Bartle 1991).

Aububon's Shearwater (Puffinus lherminieri) is a pantropical seabird but the subspecies P. l. bailloni is found only on the islands of Reunion and Europa $\left(22^{\circ} 20^{\prime} S\right.$ and $40^{\circ} 21^{\prime} E, 1$ $650 \mathrm{~km}$ from Reunion island) (Barré et al. 1996, Le Corre 2000). Three thousand to 5000 pairs breed in 235 colonies located in the interior of Reunion Island at altitudes ranging from 50 to $1500 \mathrm{~m}$ as well as on the coastal cliffs (Bretagnolle and Attié 1991). This species breeds all year round with a peak of laying between August and November. During the breeding season, Aububon's shearwater does not seem to forage further than $50 \mathrm{~km}$ from the coast (Bailey 1967, Jaquemet et al. 2004). During that time, its diet consists of $50 \%$ Stenoteuthis oualaniensis and 50\% fish (Gigan \& Lebon, pers. comm.).

Two thousand to 5000 pairs of White-tailed Tropicbirds breed in ravines or on coastal cliffs of Reunion Island. They do not form true colonies (Le Corre, unpublished data). This indigenous species breeds on the island all year long. During this period its diet consists of $80 \%$ Stenoteuthis oualaniensis and 20\% fish, mainly of the Mollidae and Dactylopteridae families (Gigan \& Lebon, pers. comm.).

Outside their breeding period individuals scatter in the tropical waters of the Indian Ocean (Barré et al. 1996). During that time, dietary habits of the three species remain unknown.

\subsection{Bird sampling}

Fifty two Barau's Petrels, 61 Audubon's Shearwaters and 49 White-tailed Tropicbirds were sampled. All birds in this study died accidentally. Petrels and shearwaters are known to be attracted by urban lights. This is particularly common in Reunion (Le Corre et al. 2001b). Of the hundreds of fledgling Petrels and Shearwaters found stranded annually, $90 \%$ are rescued successfully (Le Corre et al. 2001b). The remaining $10 \%$ are usually found dead or fatally injured. The adult Procellariiformes died of various causes including light attraction, collisions and poaching. Poaching was also one of the main causes of the death of the White-tailed Tropicbirds. Since these birds were found before or shortly after their death, we are confident that the conditions in which the birds died had no effect on the elemental levels in their tissues.

Each bird was measured, weighed and aged. Two age classes were determined (juvenile or adult) using characteristic features of the beak and the feathers. For adults, the presence of an incubation patch was an indicator of the reproductive status of the individual. Since these birds do not show any sexual dimorphism, their sex was determined during dissection. Only adults were sexed. Gonads were not developed enough in fledglings to differentiate 
males from females. The liver, kidneys and pectoral muscles were removed and refrozen for freeze drying. Breast feathers were also sampled on each bird. Emaciation was estimated by evaluating the muscular condition (MC) which was given a range from 1 to 3 in relation to the shape of the pectoral muscles : 1 , well developed pectoral muscles ; 2, slight pectoral muscle atrophy ; 3, severe pectoral muscle atrophy (Bolton et al. 1991). Body condition (BC) was also evaluated using a condition index proposed by Wenzel and Adelung (1996). This condition index is the ratio of liver to kidney masses. It is significantly negatively correlated to the degree of emaciation of the bird : the smaller the index, the more emaciated is the bird (Debacker et al. 2001a).

\subsection{Sample preparation}

Livers, kidneys and muscles were blended, dried and ground to a fine powder. Muscles were dried in an oven at $55^{\circ} \mathrm{C}$ to constant mass for $72 h$, whereas liver and kidney samples were lyophilized. The moisture content was 66 to $72 \%$ in liver, 73 to $78 \%$ in kidney and 65 to $71 \%$ in muscle.

The analysis of cadmium $(\mathrm{Cd})$, copper $(\mathrm{Cu})$, iron $(\mathrm{Fe})$, manganese $(\mathrm{Mn})$, selenium $(\mathrm{Se})$ and zinc $(\mathrm{Zn})$ calls for an extra step in the preparation protocol. Two aliquots of 50 to $400 \mathrm{mg}$ of each sample were digested with $3.5 \mathrm{ml}$ of $15 \mathrm{~N}$ nitric acid at $60^{\circ} \mathrm{C}$ for $48 \mathrm{~h}$ before being diluted in $10 \mathrm{ml}$ of deionized water. Accuracy and reproducibility of the preparation were tested by preparing 28 replicates of lobster hepatopancreas (TORT-2), dogfish liver (DOLT-2) and dogfish muscle (DORM-2) reference standards (National Research Council, Canada) and 11 blanks along with each set of samples. Glass and plastic utensils were washed with detergent, plunged in a bath of mixed nitric acid $\left(35 \mathrm{ml} . \mathrm{l}^{-1}\right)$ and hydrochloric acid $\left(50 \mathrm{ml} . \mathrm{l}^{-1}\right)$ for a minimum of $24 h$, rinsed 3 times in deionized (Milli-Q quality) water and dried in an oven at $50^{\circ} \mathrm{C}$ before use.

Pectoral feathers were washed vigorously in triple baths of $0.25 \mathrm{~N}$ sodium hydroxide solution alternated with triple baths of deionized water in order to remove adherent external contamination and airborne contamination (Walsh 1990, Burger 2001) which could alter the results of the analysis of $\mathrm{Hg}$ sequestered in the feathers. Feathers were then dried in an oven for $24 h$ at $50^{\circ} \mathrm{C}$ and analyzed for $\mathrm{Hg}$ content.

\subsection{Metal analysis}

Cadmium, Cu, Fe, Mn, Se and Zn were analyzed by Inductively Coupled Plasma Atomic Emission Spectrometry (ICP-AES Varian Vista Pro CCD). Total Hg analyzes were carried out with an Advanced Mercury Analyzer (ALTEC AMA 254) on aliquots ranging from 5 to $20 \mathrm{mg}$ of dried sample weighed to the nearest $0.01 \mathrm{mg}$.

Detection limits and recovery rates were respectively equal to $0.322 \mu \mathrm{g} \cdot \mathrm{g}^{-1}$ and $98 \%$ for Cd, $0.32 \mu g \cdot g^{-1}$ and $94 \%$ for $\mathrm{Cu}, 0.64 \mu g \cdot g^{-1}$ and $89 \%$ for Fe, $0.0025 \mu g \cdot g^{-1}$ and $94 \%$ for $\mathrm{Hg}, 0.32 \mu \mathrm{g} \cdot \mathrm{g}^{-1}$ and $90 \%$ for Mn, $6.45 \mu \mathrm{g} \cdot \mathrm{g}^{-1}$ and $85 \%$ for Se and $1.29 \mu \mathrm{g} \cdot \mathrm{g}^{-1}$ and $101 \%$ for Zn. Element levels are expressed in $\mu g \cdot g^{-1}$ of dry weight (d.w.). 


\subsection{Statistical analysis}

Statistical analyzes were performed using the GNU R statistical system (R Development Core Team 2005). All statistical samples submitted to tests were first checked for normality by means of Shapiro-Wilk tests. In the case of non-departure from normality, parametric tests were used in the subsequent analyzes, otherwise, non-parametric analogues were used.

The validity of the replicates of the level measures was tested by means of $t$-tests for paired samples. The significance of differences of trace element levels among tissues was tested by one way repeated measures analysis of variance (ANOVA) or Friedman tests and followed by Tukey's HSD (Honest Significant Difference) tests. The influence of species, age, sex, MC and reproductive status on elemental levels was tested by means of ANOVA or Kruskal-Wallis tests followed, when necessary, by Tukey's HSD tests. Prior to the use of ANOVA for independent samples, besides normality, the homogeneity of the variances of the tested samples was checked by means of Bartlett tests. In case of departure from normality or non-homogeneity of the variances, Kruskal-Wallis tests were applied instead.

For each species, associations among elemental levels in different tissues were studied by means of Pearson's linear correlation coefficient. The resulting correlation matrices were represented by dendrograms built using the average linkage as aggregation criterion.

Levels of significance of the null hypotheses associated with these tests will be divided into classes of $p$-values represented by the following codes : $N S \geq 0.05 ; *<0.05$; $* *<0.01 ; * * *<0.001$. SD will stand for standard deviation and CV for coefficient of variation.

\section{Results}

Levels of $\mathrm{Cd}, \mathrm{Cu}, \mathrm{Fe}, \mathrm{Hg}, \mathrm{Mn}$, Se and $\mathrm{Zn}$ in liver, muscle, kidney and $\mathrm{Hg}$ in feathers of each species/age subgroup are presented in Table 1 and their dispersion illustrated in Figures 1, 2 and 3.

With the exception of $\mathrm{Cu}$ which presented particularly high coefficient of variation (CV) values in Barau's Petrel liver (115\%) and the White-tailed Tropicbird kidneys (up to 117\%), essential elements showed little variability in seabird tissues. In contrast, $\mathrm{Cd}$ and $\mathrm{Hg}$ levels showed high variability in all three species. For Cd, CV values ranged from $38 \%$ to $134 \%$. For $\mathrm{Hg}$, the highest fluctuations were found in the soft tissues of the juvenile White-tailed Tropicbirds (196\%), and the lowest in their feathers (8\%). In the soft tissues, CV values were higher in juvenile than in adult tropicbirds (up to 3 times higher), whereas they were higher in adult than juvenile Procellariiformes.

Elemental levels varied from one tissue to the other, except for $\mathrm{Cu}$ for which the differences were not significant between liver and muscle (Table 1). The general pattern, in all 3 species, showed that liver (followed by kidney, then muscle) accumulated the highest levels of $\mathrm{Fe}, \mathrm{Hg}$ and $\mathrm{Mn}$. This was also the case for $\mathrm{Zn}$, except in juvenile petrels where the highest levels were found in kidney. Cadmium and Se accumulated mostly in kidney. Furthermore, muscle and feather Hg levels were equivalent in juvenile shearwaters and tropicbirds. In petrels, juveniles showed higher $\mathrm{Hg}$ levels in feathers than in muscle whereas opposite results were found for adults. 
Table 1: Levels (Mean $\pm \mathrm{SD}, \mu g \cdot g^{-1}$ d.w.) and inter-specific comparison results for 7 trace elements in the tissues of juvenile and adult seabirds from Reunion Island.

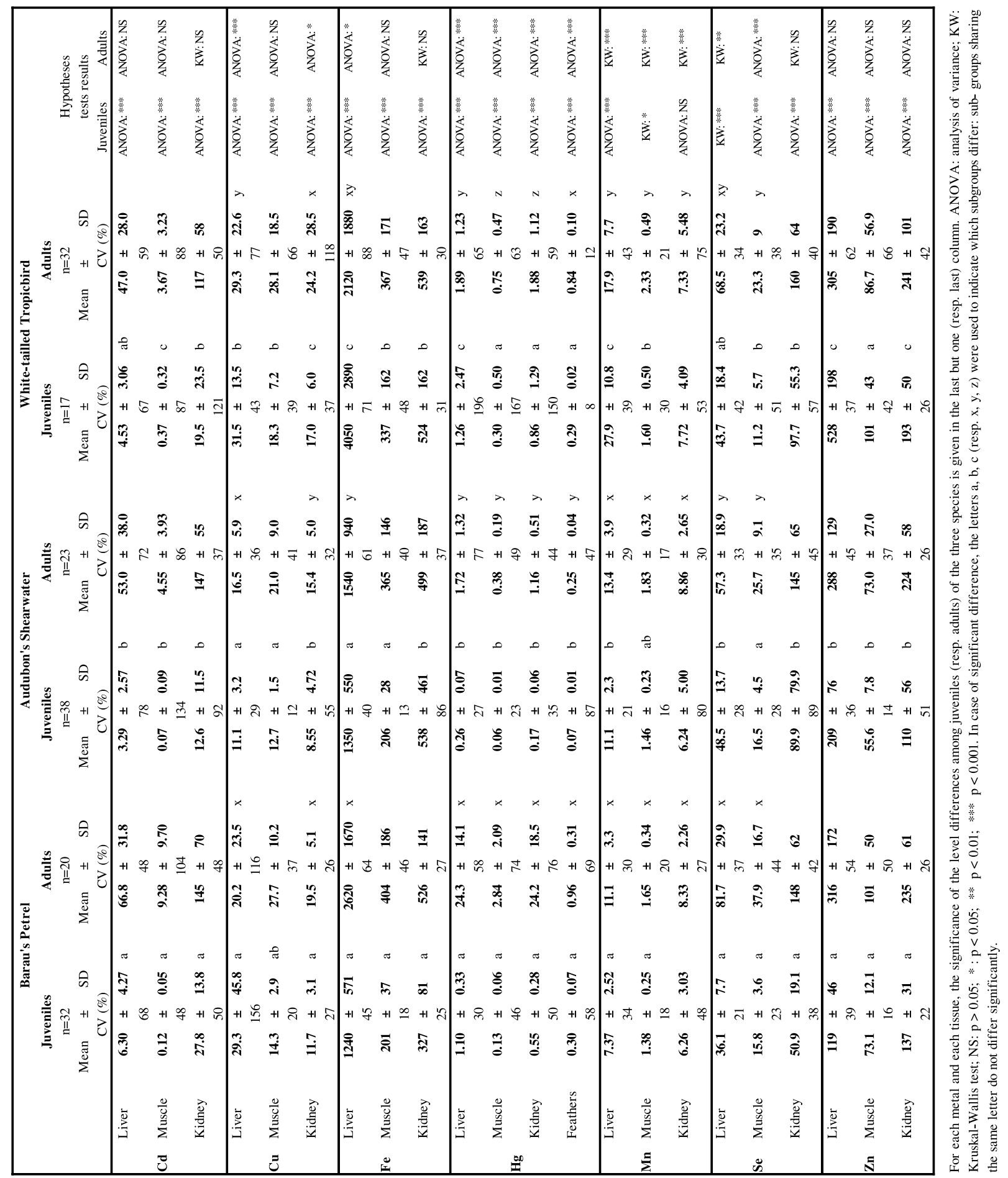

\subsection{Factors influencing trace element levels}

\subsubsection{Influence of age-classes, sex and reproductive status}

Clear morphological traits differentiate fledgling from adults, therefore, elemental burdens differences were tested between these two age-classes. The type of test and level of signif- 
Cd

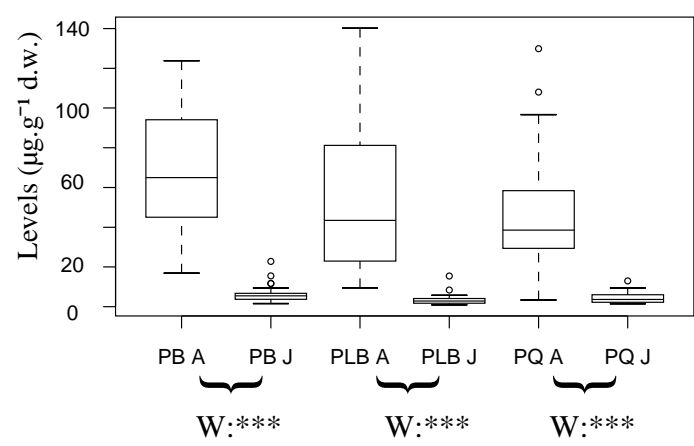

$\mathrm{Fe}$

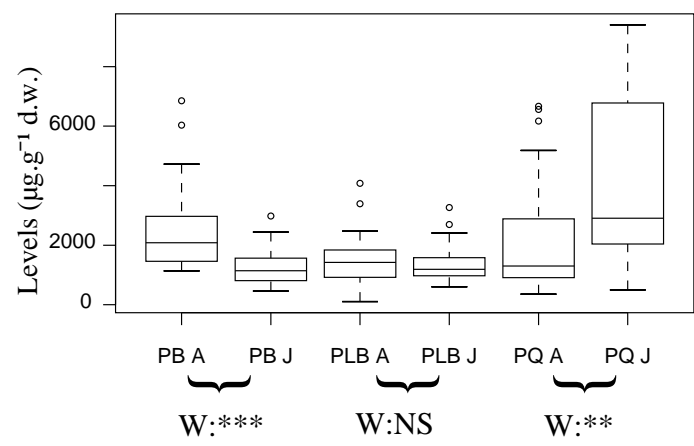

Mn

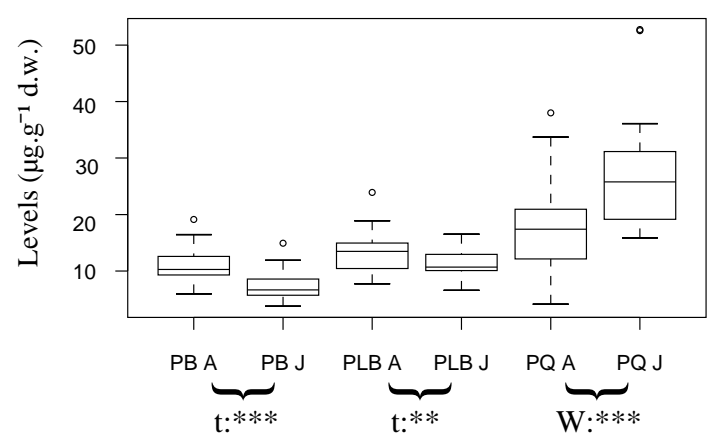

$\mathrm{Zn}$

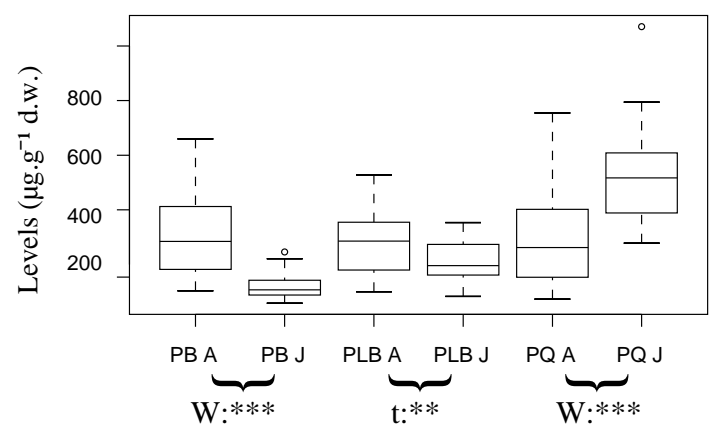

$\mathrm{Cu}$

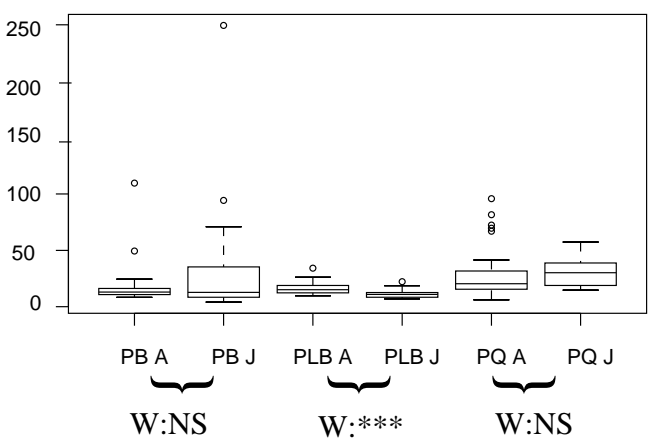

$\mathrm{Hg}$

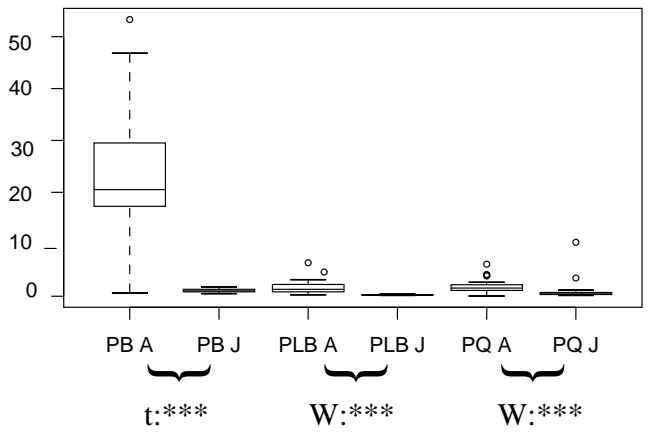

Se

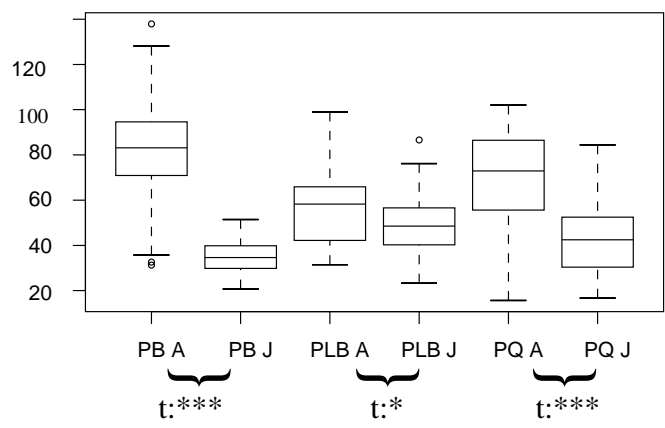

Figure 1: Comparison of elemental levels $\left(\mu g . g^{-1}\right.$ d.w.) in liver of adult (A) and juvenile (J) seabirds (PB: Pterodroma baraui, PLB: Puffinus l. bailloni, PQ: Phaethon lepturus). Outliers are represented as individual points. For each species, the significances of the level differences between juveniles and adults are indicated below the boxplots. $t: t$-test $; W$ : Wilcoxon test. 
Cd
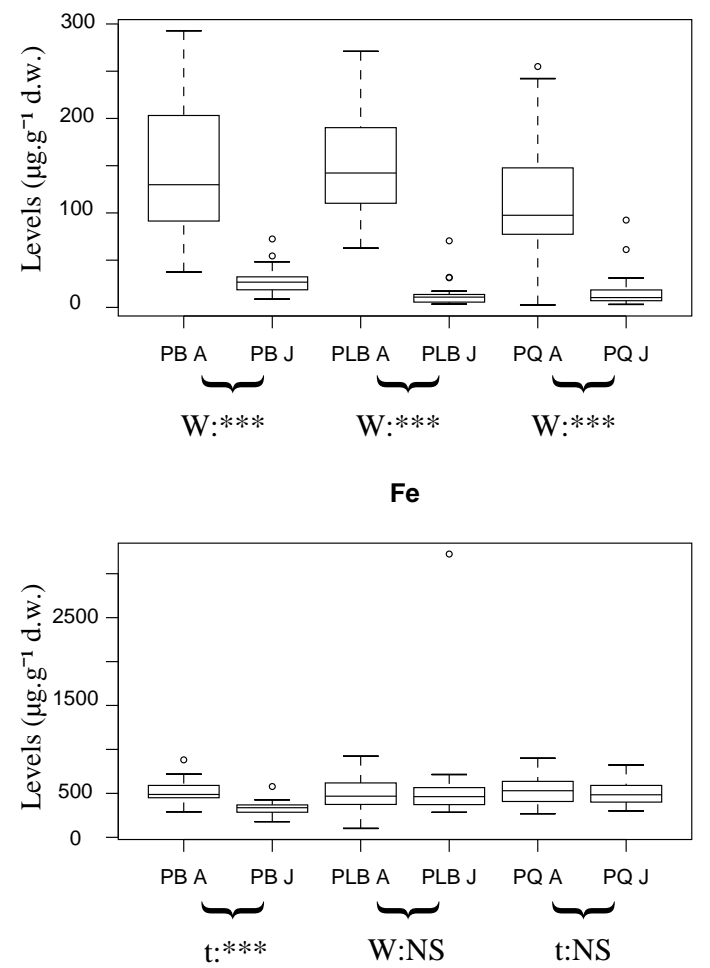

$\mathrm{Mn}$

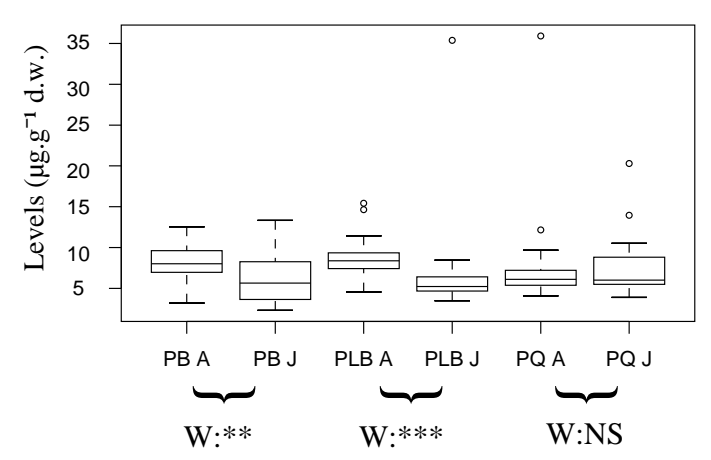

$\mathrm{Zn}$

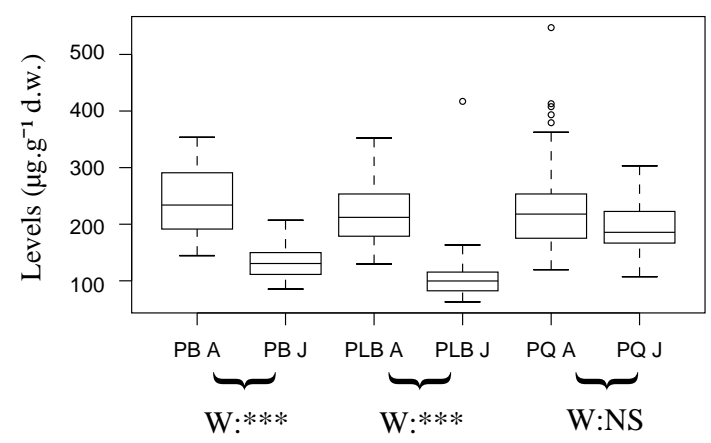

$\mathrm{Cu}$

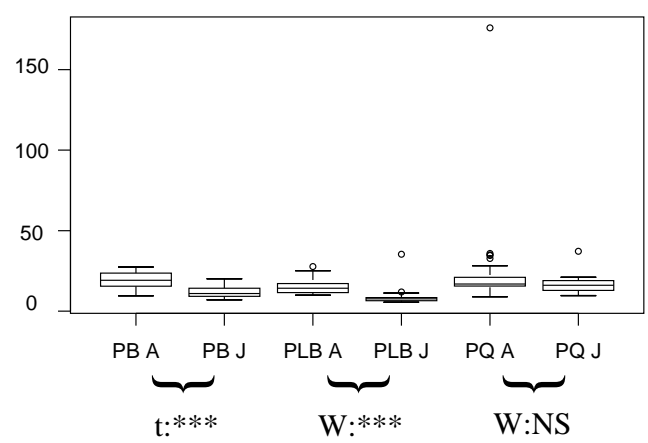

$\mathrm{Hg}$

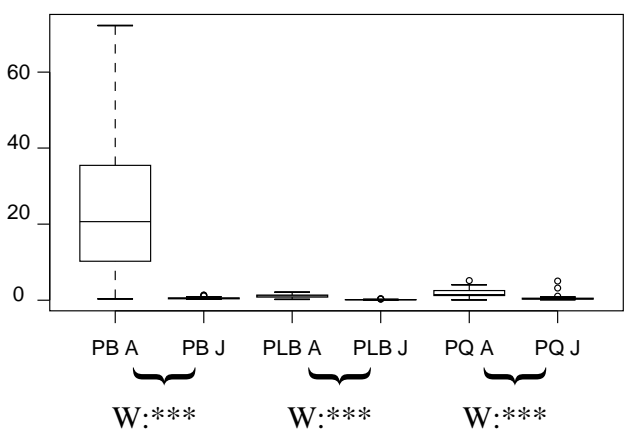

Se

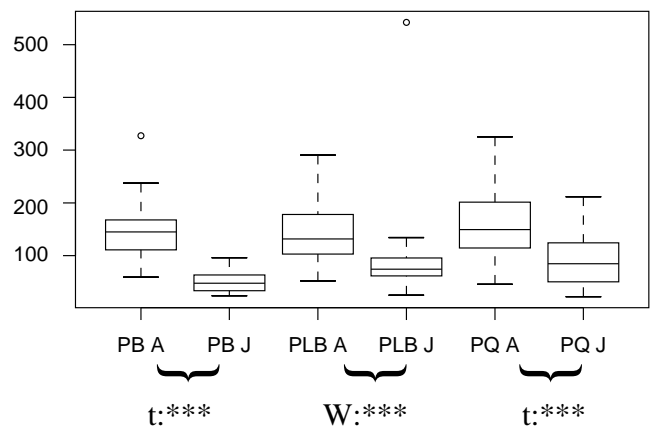

千 Non-outlier Max.

$\perp$ Non-outlier Min.

3rd quartile

Mean

1st quartile

- Outlier

Figure 2: Comparison of elemental levels $\left(\mu g . g^{-1}\right.$ d.w.) in kidneys of adult (A) and juvenile (J) seabirds (PB: Pterodroma baraui, PLB: Puffinus l. bailloni, PQ: Phaethon lepturus). Outliers are represented as individual points. For each species, the significances of the level differences between juveniles and adults are indicated below the boxplots. $t$ : $t$-test ; $W$ : Wilcoxon test. 
Cd in pectoral muscles

$\mathrm{Cu}$ in pectoral muscles
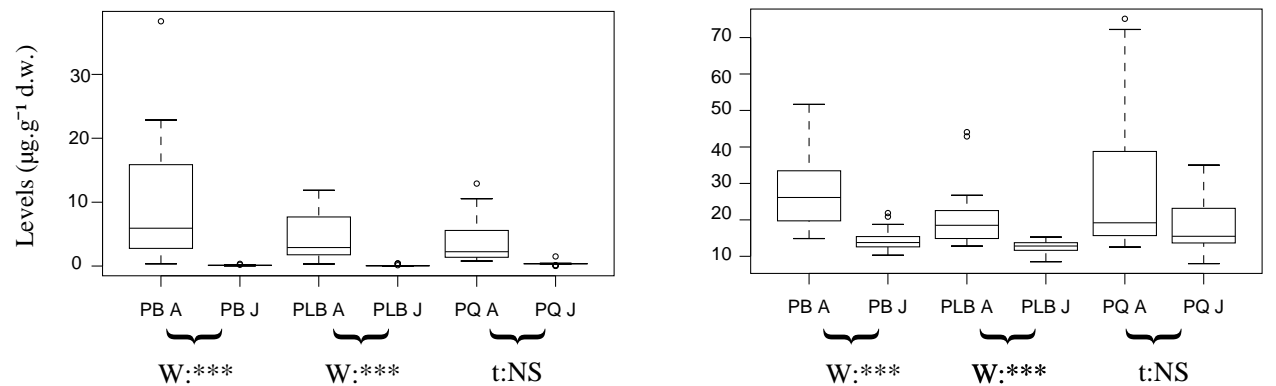

Fe in pectoral muscles

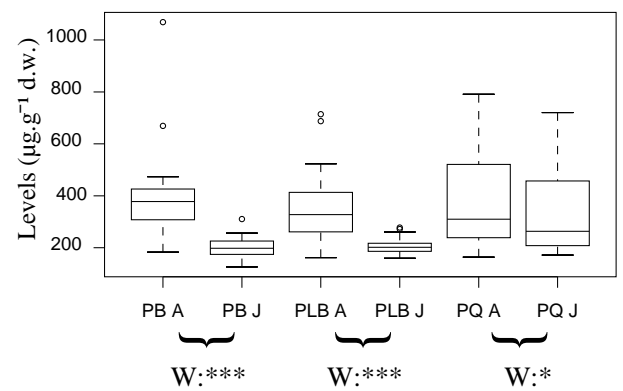

Mn in pectoral muscles
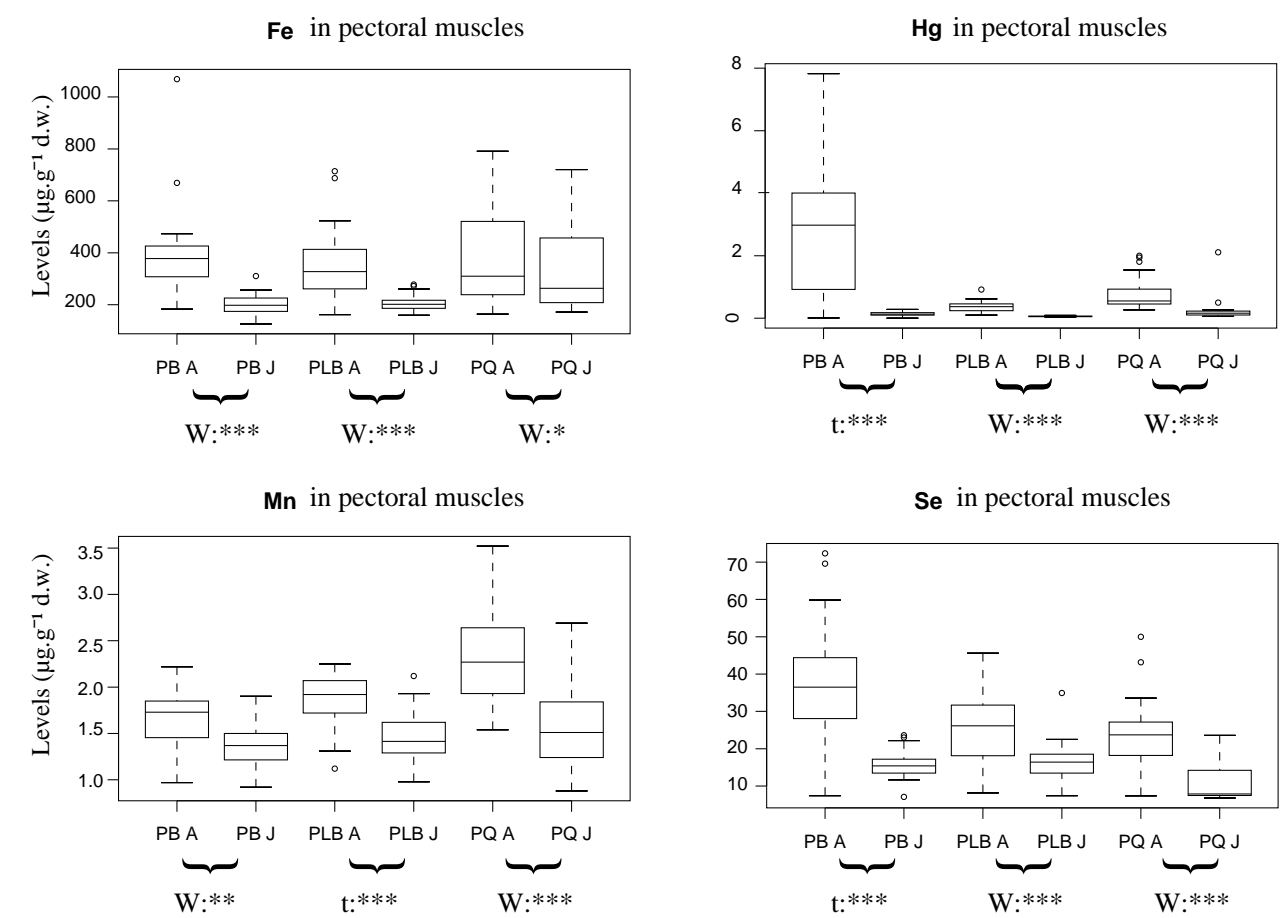

Se in pectoral muscles

Zn in pectoral muscles
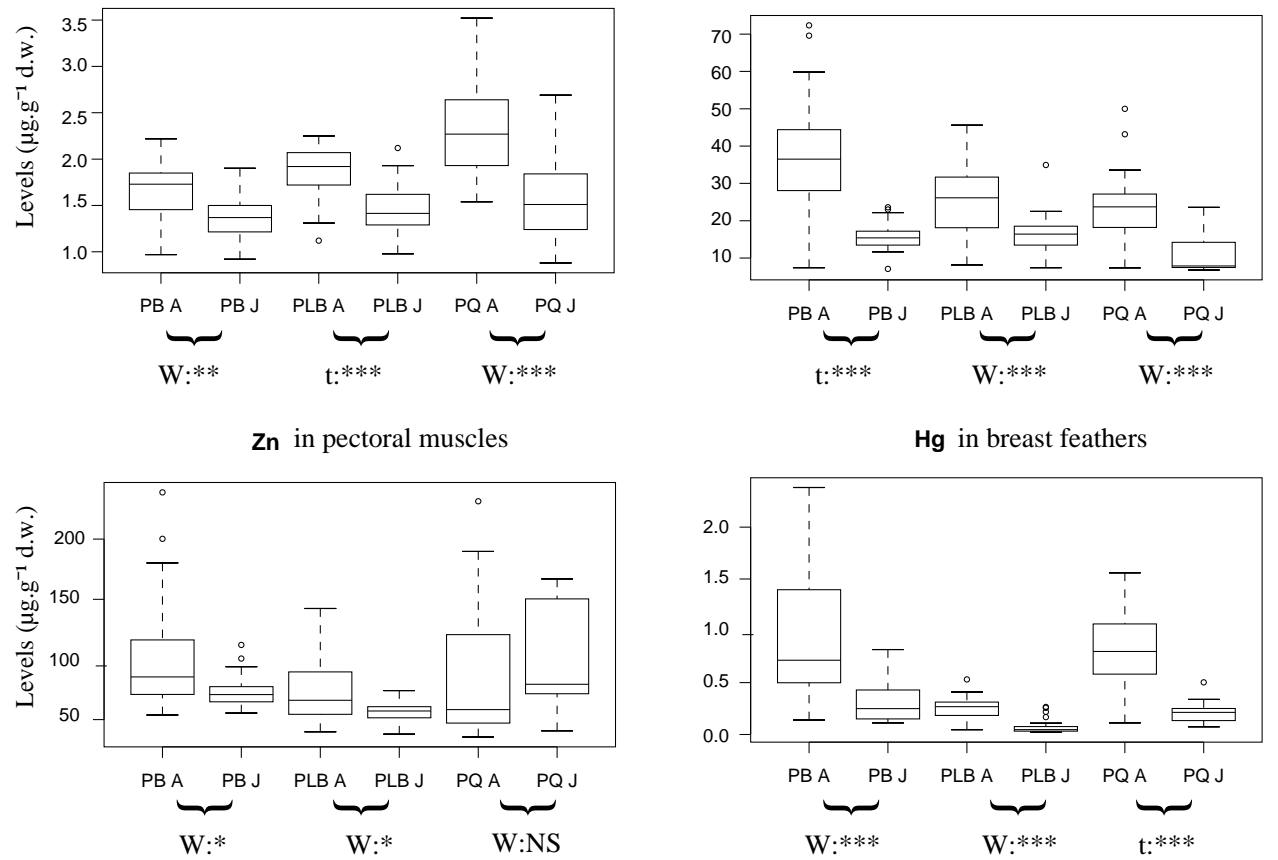

Figure 3: Comparison of elemental levels $\left(\mu g . g^{-1}\right.$ d.w.) in pectoral muscles and breast feathers of adult (A) and juvenile (J) seabirds (PB: Pterodroma baraui, PLB: Puffinus l. bailloni, PQ: Phaethon lepturus). Outliers are represented as individual points. For each species, the significances of the level differences between juveniles and adults are indicated below the boxplots. $t$ : $t$-test ; $W$ : Wilcoxon test. 
icance are given in Figures 1,2 and 3. Significantly higher elemental levels were revealed in adult petrels than in juveniles, except for hepatic $\mathrm{Cu}$. In the same way, levels were significantly higher in adult shearwaters than in juveniles, except for Fe in liver and kidney. In tropicbirds differences between juvenile and adult were less systematic with, in some cases (i.e. Fe, Mn and $\mathrm{Zn}$ ), higher levels in juveniles than in adults. In all three species, significant differences between juvenile and adults were observed in the three tissues for $\mathrm{Hg}$ and Se, for $\mathrm{Cd}$ in muscle and kidney, for $\mathrm{Mn}$ in muscle and liver as well as for Fe and $\mathrm{Zn}$ levels in liver.

The influence of sex on elemental levels was tested on adult birds. Gender did not seem to influence elemental levels among adults of each species with the exception of hepatic Se which was higher in tropicbird males than in females $\left(P_{\text {Wilcoxon }}: * * *\right)$. This latter result suggests that eggs may constitute an excretion path for Se in female White-tailed Tropicbirds.

Reproductive status, defined by the presence or absence of an incubation patch, did not significantly influence trace element levels among adults for all species.

\subsubsection{Inter-specific differences}

Elemental levels also differed among species (Table 1). In juveniles, significant differences were found for every element in every tissue of the three species except for renal Mn. Mercury levels were significantly higher in Barau's petrels and White-tailed Tropicbirds than in Audubon's Shearwaters. The highest levels of Cd were found in the petrels. Essential metals $(\mathrm{Cu}, \mathrm{Fe}, \mathrm{Mn}$ and $\mathrm{Zn})$ levels were highest in the tropicbirds.

As far as the adults were concerned, there were fewer differences among species. Mercury was the only element for which there were differences between adults of all species. The highest $\mathrm{Hg}$ levels were found in Barau's Petrel and the lowest in Audubon's shearwater. Adult Barau's Petrel also had the highest Fe and Se levels. The highest levels of $\mathrm{Cu}$ and $\mathrm{Mn}$ were found in the White-tailed Tropicbird. There were no significant differences between $\mathrm{Cd}$ and Zn levels in the three species.

\subsection{Relationships between trace element levels}

The correlation matrices among elemental levels in the various tissues of each species were not presented in this paper. However, two types of linear correlations were obvious : (i) correlations between different elements in the same tissue and, (ii) correlations of levels of one element in various tissues. (i) Mercury and Cd stood out by their strong tissue-to-tissue correlations in all species. Selenium and Mn were also well correlated in the liver, kidney and muscle of Barau's petrel. (ii) The following significant correlation between elements were common to the three species: $\mathrm{Cu}, \mathrm{Fe}$ and $\mathrm{Zn}$ in muscle, and $\mathrm{Fe}$ and $\mathrm{Zn}$ in liver. Other relationships were more species-specific, such as correlations between $\mathrm{Mn}$ and Se in muscle, $\mathrm{Cu}$ and $\mathrm{Mn}$ in kidney in the tropicbird and renal $\mathrm{Cu}, \mathrm{Fe}, \mathrm{Mn}$, Se and $\mathrm{Zn}$ in the shearwater. 


\section{Discussion}

\subsection{Bioaccumulation in Barau's Petrel, Audubon's Shearwater and the White-tailed Tropicbird}

\subsubsection{Tissue distribution}

As it has often been shown, trace elements are not all identically distributed in the different tissues of the organism. The preferential accumulation of $\mathrm{Fe}, \mathrm{Hg}, \mathrm{Mn}$ and $\mathrm{Zn}$ in the liver of Reunion birds reflects the usual trends, as does the preferential accumulation of $\mathrm{Cd}$ in kidney (Furness and Rainbow 1990, Furness et al. 1993, Thompson et al. 1996). Indeed, liver and kidney are considered as long-term storage tissues for $\mathrm{Hg}$ and $\mathrm{Cd}$ in seabirds (Walsh 1990), implying that large birds with long life span accumulate high burdens of these elements (Fiona et al. 1999). This is obvious in Procellariiformes, for which the albatrosses are the best example (Hindell et al. 1999), and seems to apply to this study where Barau's Petrel is the largest of the two Procellariiforme species and shows the highest levels.

The equal distribution of $\mathrm{Cu}$ between liver and muscle in all three studied species is an unexpected result. This accumulation pattern has, however, already been observed, although not explained, in the Common Diving Petrel (Pelecanoides urinatrix), the South Georgian Diving Petrel (Pelecanoides georgicus) and the Antarctic Prion (Pachyptila desolata) from the Kerguelen archipelago (Bocher et al. 2003). Selenium also differs from the usual distribution pattern as it is mostly accumulated in the kidneys of the studied birds. There are few data on the distribution of Mn among seabird tissues. It was found mainly in the liver and kidney of Procellariiformes studied by Kim et al. (1998) and mainly in the liver of Reunion birds. Further studies are needed to determine the bioaccumulation pattern of Mn in seabird tissues.

\subsubsection{Influence of phylogeny}

Tropicbirds belong to the Phaethontidae family whereas the other two species are from the Procellariidae family. Only in the tropicbirds did juveniles have higher essential metal levels than adults. This same pattern has already been observed in various species (Kim et al. 1998, Stewart et al. 1999) in which the young accumulate essential elements to meet particularly high nutritional needs (Thompson et al. 1996). This strategy may have evolved in order to survive the fast caused by the abandon of the fledglings by their parents several days before their first flight. Since young Procellariiformes also undergo a long fasting period before fledging, but do not have high essential elemental levels, the White-tailed Tropicbird may differ from the two Procellariiforme species in the way its metabolism deals with the accumulation of such essential elements.

Procellariiformes have been cited for their particular ability to concentrate trace elements, resulting in much higher elemental burdens than many other seabirds (Walsh 1990). However, within the Procellariiformes order, phylogeny is thought to explain relatively little of the inter-specific variations (Fiona et al. 1999). Other than intrinsic differences in bioaccumulation linked to phylogeny, several characteristics of a species may explain part of the inter-specific variability.

Size and life span obviously have an impact on the quantity of trace elements concen- 
trated in the body because of a dilution effect and because longer living species have more time to accumulate larger burdens. Among the three species, Barau's petrel is the largest $(400 \mathrm{~g})$ and very likely the longest living seabird since its phylogenetically and geographically closest parent, the Galapagos Petrel Pterodroma phaeopygia, lives more than 25 years. Barau's Petrel is followed by the White-tailed Tropicbird, $260 \mathrm{~g}$, and Audubon's Shearwater, $200 \mathrm{~g}$, both having a life span superior to 20 years (Weimerskirch 2001). This pattern is respected for most trace element levels analyzed here, especially non-essential elements.

Diet is considered as one of the most important factors of trace element variability since it is the major contamination path in marine vertebrates (Stewart et al. 1999, Thompson et al. 1998, Kim et al. 1998). Of the three Reunion species, Barau's Petrel has, by far, the highest $\mathrm{Hg}$ content in the studied tissues. Fish prey are known to be a source of contamination for top predators because they accumulate high levels of $\mathrm{Hg}$ (Honda et al. 1990), mainly in a bioavailable form, i.e. methylmercury (Bloom 1992). However, Barau's Petrel only includes $2 \%$ fish in its diet but feeds on cephalopods of the Taonius genus (Le Corre, unpubl. data). These are meso-pelagic squids which live in depth ranging from 500 to $700 \mathrm{~m}$ (Clarke 1986, Nesis 1987). It is thought that Barau's Petrel feeds on their floating carcasses. The deep, poorly oxygenated waters promote the methylation of $\mathrm{Hg}$ which is easily transfered to living organisms (Thompson et al. 1998). Recently, relatively high $\mathrm{Hg}$ levels were reported in mesopelagic cephalopods from the north-eastern Atlantic waters, in which a major proportion of $\mathrm{Hg}$ was in an organic form (Bustamante et al. 2006). These findings are consistent with the fact that $\mathrm{Hg}$ levels found in pelagic marine birds are higher than those found in terrestrial birds (Monteiro et al. 1996, Thompson et al. 1998). High Hg levels in Taonius could be responsible for the higher $\mathrm{Hg}$ levels found in Barau's Petrel.

Procellariiformes are also known for having high Cd levels due to their diet, which is essentially composed of cephalopods, and cephalopods have been shown to be responsible for the high Cd levels in top predators (Smith et al. 1984, Bustamante et al. 1998a, Bustamante et al. 1998b). This seems to be the case in Reunion Procellariiformes and especially in Barau's Petrel since $98 \%$ of its diet is composed of cephalopods (Gigan \& Lebon, unpublished data). The study of $\mathrm{Hg}$ and $\mathrm{Cd}$ burdens of the various prey species of the three birds would be useful in confirming these hypotheses.

\subsubsection{Inter-individual differences}

The high individual fluctuations observed for $\mathrm{Cd}, \mathrm{Cu}$ and $\mathrm{Hg}$ could have many causes such as individual variation in diet (see 4.1.2), body condition and age (within an age-class).

The White-tailed Tropicbird was the only species for which the individual variations of $\mathrm{Hg}$ burdens were higher in juveniles than in adults. This may be explained by a difference in their breeding cycle. Contrary to the Procellariiformes species which breed on Reunion Island at definite periods, Tropicbirds breed individually thoughout the year. As Hg intake originates from diet, young Tropicbirds collected in various periods of the year would show more inter-individual variations than young Petrels or Shearwaters which were all collected roughly at the same time. Furthermore, these large inter-individual differences would not be as apparent in adult Tropicbirds which would have integrated $\mathrm{Hg}$ over a longer period, thus minimizing the variability.

Individual fluctuation in elemental levels was also found to be induced by a variability in the nutritional condition of the Common Guillemots (Uria aalge) at death (Debacker et 
al. 2001b). The influence of muscle condition (MC) and body condition (BC) on elemental levels was studied to determine whether the body condition of these birds had an influence on the results. As a general trend, most significant differences in trace element levels existed between the MC indices 1 and 3, which are two extreme cases, i.e. well fed and starving birds $\left(P_{\text {Wilcoxon }}: *\right)$. Only renal Fe, muscular $\mathrm{Mn}$, and Se levels in liver and kidney seemed unaffected by the bird's muscular condition. The higher elemental levels in the starving birds were most probably due to the loss of weight of the tissue rather than to a raise of the elemental levels. Surprisingly, very few significant correlations were found between the $\mathrm{BC}$ index (which ranged from 0.7 to 4.5 ) and trace element levels.

It is not possible to estimate the age of adult seabirds unless they are marked, yet trace elements are known to be accumulated in the organism over the lifetime. Age can therfore be considered as a possible cause of individual fluctuation among adults of each species.

\subsubsection{Relationships between trace element levels}

The evolution of $\mathrm{Hg}$ tissue-to-tissue correlations in Barau's Petrel juveniles and adults is a good illustration of the bioaccumulation of this element. Indeed, significant correlations of $\mathrm{Hg}$ levels were observed between feathers, liver, kidney and muscle in juvenile petrels $(r=0.371 *$ to $r=0.717 * * * ; n=32)$. In adults, $\mathrm{Hg}$ levels in liver, kidney and muscle remained correlated ( $r=0.58 * *$ to $r=0.786 * * * ; n=20$ ) whereas feather $\mathrm{Hg}$ levels were no longer significantly correlated to the others. Once the feather is formed, the blood irrigation subsides, implying that no further metal is deposited. In adult Barau's Petrel, $\mathrm{Hg}$ burden in the feathers had not evolved since the last plumage growth, whereas $\mathrm{Hg}$ levels in the other organs had increased with $\mathrm{Hg}$ accumulation.

Correlations between elements, such as $\mathrm{Cu}, \mathrm{Fe}$ and $\mathrm{Zn}$ in muscle and $\mathrm{Fe}$ and $\mathrm{Zn}$ in liver of the three species, suggested that uptake and pathways of metabolism and storage are relatively similar for these trace elements.

\subsection{Comparison with other species and locations}

Table 2 draws a parallel between elemental levels in liver, kidney and feathers in seabirds from Reunion Island and phylogenically related species from other locations in the world. Elemental burdens in juveniles and adults are presented separately.

Most ecotoxicological works are based on the study of adults, as they have integrated the environmental contamination over a longer period of time. Metal levels obtained for adults in this study are generally comparable to those reported for petrels and shearwaters studied in other oceanic islands (Muirhead and Furness 1988, Stewart et al. 1994, Stewart et al. 1997a, Stewart et al. 1999). Nevertheless, Se and Zn values observed in these birds were fairly high. In kidney, Se levels exceeded 3.6 to 4.5 times the value of $10 \mu g \cdot g^{-1}$ wet weight $\left(\approx 40 \mu g \cdot g^{-1}\right.$ d.w) considered as the level above which Se may have harmful effects on birds (Thompson et al. 1996). This indicates that regulation mecanisms must exist in Reunion birds. Similar Se concentrations have been observed in other wild seabirds such as Leach's Storm-petrel (Oceanodroma leucorrhoa, $78 \mu . g^{-1}$ d.w.) from the Atlantic coast of Canada (Elliott et al. 1992), the Black-footed Albatross (Diomedea nigripes, $113 \mu . g^{-1}$ d.w.) from the Northern Pacific as well as birds from relatively pristine areas such as the Grey Petrel (Procellaria cinerea, $100 \mu . g^{-1}$ d.w.) from the Southern Indian Ocean (Kim et al. 1996a, Kim et al. 1998). 
Table 2: Trace element levels (Mean \pm SD, $\mu g . g^{-1}$ d.w.) in seabirds from different biogeographical areas: 1: Tropical ; 2: Subtropical ; 3: Temperate ; 4: Subpolar. ${ }^{*}$ designates species for which data have been converted from "wet weight" to "dry weight" assuming a tissue water content of $70 \%$.

\begin{tabular}{|c|c|c|c|c|c|c|c|c|c|c|c|c|c|c|c|c|c|c|c|c|c|}
\hline 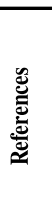 & $\begin{array}{l}\text { 誊 } \\
\text { 啇 }\end{array}$ & $\begin{array}{l}\text { 訔 } \\
\text { 产 } \\
\text { 音 }\end{array}$ & 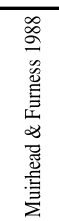 & 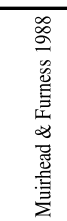 & 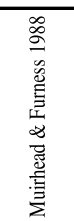 & 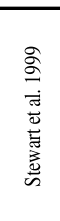 & 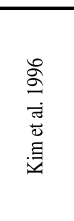 & 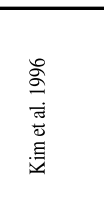 & 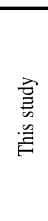 & 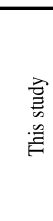 & 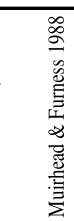 & 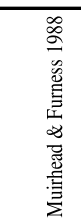 & 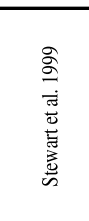 & 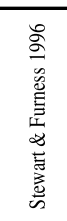 & 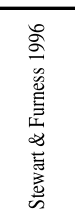 & 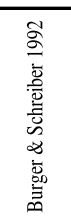 & 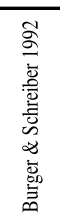 & & 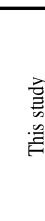 & 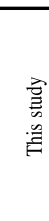 & 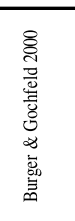 \\
\hline 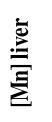 & $\begin{array}{l}\text { on } \\
\text { in } \\
+1 \\
\text { ñ } \\
n\end{array}$ & $\begin{array}{l}\infty \\
\stackrel{\infty}{+} \\
+1 \\
\stackrel{\Xi}{\Theta}\end{array}$ & & & & & & & 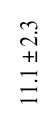 & $\begin{array}{l}\underset{m}{2} \\
+1 \\
+1 \\
\stackrel{+1}{m}\end{array}$ & & & & & & & & & $\begin{array}{l}\infty \\
\stackrel{0}{0} \\
+1 \\
\stackrel{े}{二}\end{array}$ & $\begin{array}{l}\stackrel{\overline{+}}{+1} \\
\stackrel{+}{\Xi}\end{array}$ & \\
\hline 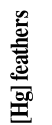 & $\begin{array}{l}\overline{0} \\
+1 \\
0 \\
0\end{array}$ & $\begin{array}{l}\overrightarrow{3} \\
\stackrel{0}{0} \\
+1 \\
\stackrel{0}{0}\end{array}$ & & & & & & & $\begin{array}{l}\vec{a} \\
0 \\
+1 \\
+1 \\
0 \\
0\end{array}$ & $\begin{array}{l}\text { to } \\
\text { +े } \\
\text { +1 } \\
\text { à }\end{array}$ & & & & & & $\begin{array}{l}\tilde{\infty} \\
\tilde{o} \\
+1 \\
\infty \\
\infty \\
\infty\end{array}$ & $\begin{array}{l}\stackrel{3}{1} \\
+1 \\
\stackrel{+1}{a}\end{array}$ & 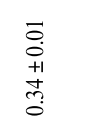 & $\begin{array}{l}\tilde{0} \\
\text { +े } \\
\text { +े } \\
\text { శे }\end{array}$ & $\begin{array}{l}0 \\
0 \\
+1 \\
+ \\
+ \\
0 \\
0\end{array}$ & $\begin{array}{l}n \\
\tilde{a} \\
+1 \\
\stackrel{+1}{f}\end{array}$ \\
\hline 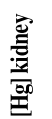 & \begin{tabular}{l}
$\infty$ \\
\multirow{3}{0}{} \\
+1 \\
in \\
in
\end{tabular} & 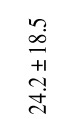 & & & & $\underset{\sim}{\infty}$ & & & $\begin{array}{l}\stackrel{0}{0} \\
+1 \\
+1 \\
\\
0\end{array}$ & $\begin{array}{l}\bar{n} \\
0 \\
+1 \\
\stackrel{0}{=}\end{array}$ & & & 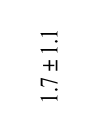 & & & & & & 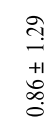 & $\begin{array}{l}\stackrel{7}{7} \\
\stackrel{+1}{+1} \\
\stackrel{\infty}{\infty}\end{array}$ & \\
\hline 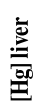 & $\begin{array}{l}m \\
\stackrel{+}{+1} \\
= \\
=\end{array}$ & $\begin{array}{c}\vec{J} \\
\underset{+1}{+1} \\
\stackrel{7}{J}\end{array}$ & $\begin{array}{l}n \\
n \\
+1 \\
n \\
n \\
n\end{array}$ & $\begin{array}{l}\widehat{\sigma} \\
\approx \\
+1 \\
\sim \\
\alpha\end{array}$ & $\begin{array}{l}0 \\
0 \\
0 \\
+1 \\
0 \\
0\end{array}$ & $\stackrel{m}{N}$ & 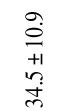 & $\begin{array}{l}\stackrel{g}{\partial} \\
+1 \\
\stackrel{+}{=}\end{array}$ & $\begin{array}{l}\bar{a} \\
0 \\
+1 \\
\text { +1 } \\
0 \\
0\end{array}$ & $\begin{array}{l}\underset{m}{+1} \\
\stackrel{+1}{\stackrel{5}{I}}\end{array}$ & $\begin{array}{l}n \\
2 \\
i \\
+1 \\
0 \\
0 \\
0\end{array}$ & $\begin{array}{l}\stackrel{8}{-} \\
\stackrel{+}{+1} \\
\stackrel{2}{\sigma}\end{array}$ & 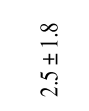 & & & & & & 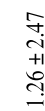 & 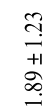 & \\
\hline 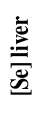 & 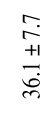 & $\begin{array}{c}\stackrel{\infty}{+1} \\
+1 \\
\stackrel{\infty}{\infty}\end{array}$ & & & & & 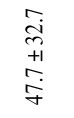 & $\begin{array}{l}n \\
n \\
+1 \\
\stackrel{8}{8}\end{array}$ & 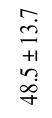 & 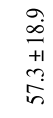 & & & & & & & & & $\begin{array}{l}+ \\
\infty \\
\stackrel{\infty}{+1} \\
\stackrel{+}{g}\end{array}$ & 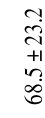 & \\
\hline 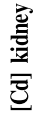 & 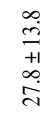 & 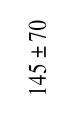 & $\begin{array}{l}0 \\
\infty \\
+1 \\
\stackrel{\infty}{1} \\
.\end{array}$ & 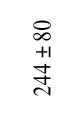 & $\begin{array}{l}8 \\
\stackrel{8}{+1} \\
\stackrel{+}{=}\end{array}$ & $\stackrel{\oplus}{\oplus}$ & & & $\begin{array}{l}\stackrel{n}{=} \\
\stackrel{+1}{+1} \\
\stackrel{0}{0} \\
\text { Ij }\end{array}$ & $\begin{array}{l}\text { n } \\
+1 \\
r \\
\text { g }\end{array}$ & \begin{tabular}{l}
$\infty$ \\
$\infty$ \\
+1 \\
\multirow{2}{*}{}
\end{tabular} & $\begin{array}{l}\stackrel{8}{\circ} \\
\stackrel{1}{I} \\
\Xi\end{array}$ & $\begin{array}{l}\stackrel{b}{b} \\
+1 \\
\underline{n}\end{array}$ & $\begin{array}{l}\infty \\
\stackrel{\infty}{+1} \\
\Xi\end{array}$ & $\begin{array}{l}\vec{\Xi} \\
\overline{+1} \\
\vec{a}\end{array}$ & & & & 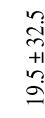 & $\begin{array}{l}\infty \\
\cdots \\
\stackrel{+1}{=}\end{array}$ & \\
\hline 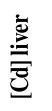 & 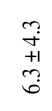 & $\begin{array}{l}\infty \\
\dot{m} \\
+1 \\
+ \\
0 \\
0 \\
0\end{array}$ & $\begin{array}{l}0 \\
\stackrel{j}{J} \\
+1 \\
\stackrel{2}{\sigma}\end{array}$ & 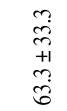 & $\begin{array}{l}\stackrel{\infty}{+} \\
+1 \\
\stackrel{+}{\sigma}\end{array}$ & $\stackrel{\infty}{\stackrel{m}{\infty}}$ & & & $\begin{array}{l}\tilde{n} \\
i \\
i+1 \\
\text { iे }\end{array}$ & $\begin{array}{l}\infty \\
\stackrel{\infty}{+} \\
\stackrel{+1}{n} \\
i\end{array}$ & $\begin{array}{l}2 \\
\frac{\partial}{+1} \\
\dot{\sigma} \\
\sigma\end{array}$ & 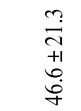 & 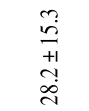 & 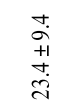 & 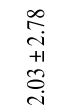 & & & & 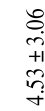 & \begin{tabular}{l} 
I \\
+1 \\
\multirow{f}{*}{}
\end{tabular} & \\
\hline 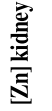 & $\begin{array}{l}0 \\
+ \\
+1 \\
m \\
m\end{array}$ & $\begin{array}{l}\overrightarrow{5} \\
+1 \\
\stackrel{+}{\sim}\end{array}$ & $\begin{array}{l}\stackrel{+}{+} \\
+1 \\
\stackrel{0}{\infty}\end{array}$ & 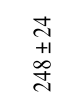 & $\begin{array}{l}+ \\
+ \\
+1 \\
\stackrel{+}{+1}\end{array}$ & $\exists$ & & & $\begin{array}{l}\stackrel{0}{n} \\
+1 \\
\stackrel{O}{\Xi}\end{array}$ & \begin{tabular}{l}
$\infty$ \\
$\stackrel{2}{+1}$ \\
+1 \\
+ \\
\multirow{N}{*}{}
\end{tabular} & 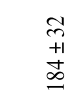 & $\begin{array}{l}0 \\
\stackrel{0}{0} \\
\stackrel{0}{0}\end{array}$ & $\begin{array}{l}\stackrel{+}{+1} \\
+1 \\
+ \\
\end{array}$ & $\begin{array}{l}\overrightarrow{7} \\
+1 \\
\stackrel{+}{n}\end{array}$ & $\begin{array}{l}\stackrel{+}{+} \\
\stackrel{+}{+} \\
\cong \\
\cong\end{array}$ & & & & $\begin{array}{l}8 \\
\vdots \\
1 \\
9\end{array}$ & $\frac{\vec{\Xi}}{\stackrel{+}{ \pm}}$ & \\
\hline 鴶 & 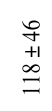 & $\begin{array}{l}\stackrel{\tilde{I}}{ \pm} \\
\stackrel{+1}{0}\end{array}$ & 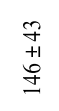 & $\begin{array}{l}\text { సิ } \\
\text { +1 } \\
\stackrel{0}{6}\end{array}$ & 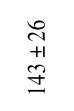 & 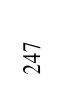 & & & $\begin{array}{l}0 \\
+1 \\
\text { +1 }\end{array}$ & 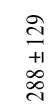 & $\underset{\simeq}{\stackrel{+1}{\beth}}$ & $\begin{array}{l}\Re \\
\underset{1}{+1} \\
\cong \\
\cong\end{array}$ & $\begin{array}{l}\frac{3}{3} \\
+1 \\
+1 \\
3 \\
3\end{array}$ & $\begin{array}{l}m \\
\stackrel{m}{+1} \\
\stackrel{0}{n} \\
\stackrel{n}{n}\end{array}$ & $\begin{array}{l}0 \\
\infty \\
+\infty \\
+1 \\
\Xi\end{array}$ & & & & $\begin{array}{l}\infty \\
\stackrel{\infty}{\circ} \\
\stackrel{+}{\infty} \\
\tilde{\sim}\end{array}$ & 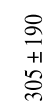 & \\
\hline 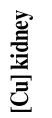 & $\begin{array}{l}\vec{m} \\
+1 \\
\stackrel{+}{ \pm}\end{array}$ & 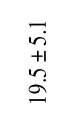 & 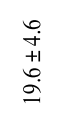 & 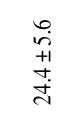 & 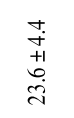 & 는 & & & 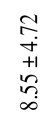 & $\begin{array}{l}n \\
+1 \\
+1 \\
+ \\
n\end{array}$ & $\begin{array}{l}\infty \\
\stackrel{+1}{+1} \\
+ \\
+\end{array}$ & $\begin{array}{l}\stackrel{a}{\vec{\lambda}} \\
+1 \\
\stackrel{+}{J} \\
\stackrel{\sim}{J}\end{array}$ & $\stackrel{\text { In }}{\stackrel{+1}{\leftrightarrows}}$ & $\begin{array}{l}n \\
0 \\
+1 \\
0 \\
0 \\
m\end{array}$ & 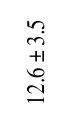 & & & & $\begin{array}{l}{ }_{1}^{\circ} \\
+1 \\
\infty\end{array}$ & 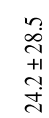 & \\
\hline 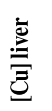 & 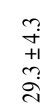 & 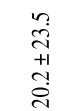 & 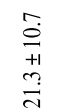 & 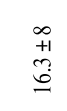 & $\begin{array}{l}\overrightarrow{0} \\
+1 \\
+1 \\
\Xi \\
\Xi\end{array}$ & తి & & & $\begin{array}{l}\stackrel{\tilde{Z}}{+} \\
\stackrel{+}{=}\end{array}$ & $\begin{array}{l}a \\
n \\
+1 \\
+1 \\
0 \\
0\end{array}$ & 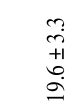 & $\begin{array}{l}+ \\
+ \\
+ \\
+1 \\
\stackrel{N}{+}\end{array}$ & $\begin{array}{l}\infty \\
\stackrel{0}{+} \\
+1 \\
\stackrel{+1}{0}\end{array}$ & $\begin{array}{l}\circ \\
\stackrel{+}{+1} \\
0 \\
\stackrel{\sim}{\sim}\end{array}$ & $\begin{array}{l}\stackrel{+}{+} \\
\stackrel{+1}{n} \\
\stackrel{\Xi}{=}\end{array}$ & & & & $\begin{array}{l}n \\
m \\
+1 \\
m \\
m\end{array}$ & $\begin{array}{l}\text { I. } \\
+1 \\
+1 \\
\text { aे }\end{array}$ & \\
\hline 道 & $\sim$ & $\varangle$ & $\varangle$ & $\varangle$ & $\varangle$ & $\varangle$ & $\varangle$ & $\varangle$ & - & $\varangle$ & $\varangle$ & $\varangle$ & $\varangle$ & $\varangle$ & - & $\varangle$ & - & $\varangle$ & - & $\varangle$ & $\varangle$ \\
\hline 吾 & - & - & $m$ & $m$ & $m$ & $\stackrel{m}{\lambda}$ & t & $\checkmark$ & - & - & $m$ & $m$ & $\frac{d}{4}$ & $m$ & $\stackrel{m}{\lambda}$ & - & - & $\alpha$ & - & - & $\sim$ \\
\hline$=$ & $\tilde{m}$ & ¿ & \pm & $\cong$ & $\stackrel{\infty}{\simeq}$ & - & $m$ & in & $\stackrel{\infty}{m}$ & $\approx$ & $\simeq$ & 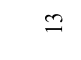 & $r$ & $=$ & $\approx$ & $\approx$ & $\simeq$ & $\sim$ & & $\approx$ & $\approx$ \\
\hline 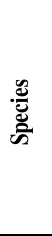 & 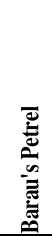 & $\bar{g}$ & $\bar{s}$ & & 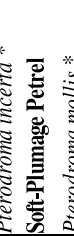 & 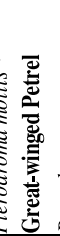 & 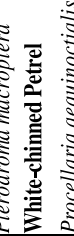 & 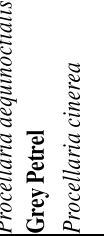 & & & & 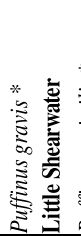 & 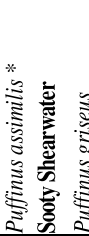 & 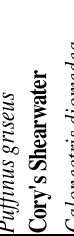 & 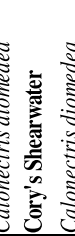 & 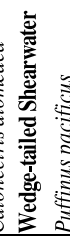 & 㺃 & 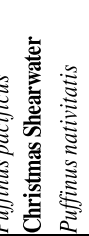 & & & 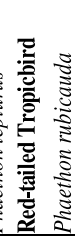 \\
\hline
\end{tabular}

The Phaethon genus has received very limited attention regarding elemental bioaccumulation. Feather Hg levels in Reunion's White-tailed Tropicbird are more than seven times inferior to those found in Red-Tailed Tropicbirds from Midway Island (Burger and Gochfeld 2000). In Barau's Petrel feathers, $\mathrm{Hg}$ levels fit in the 0.6-2.7 $\mu g . g^{-1}$ range that 
has been reported for petrels and shearwaters (Burger 1993). For Hg in feathers, a range of $5-40 \mu g . g^{-1} d . w$. can be considered as associated with adverse effects (Eisler 1987, Burger and Gochfeld 1997). In this study, the highest $\mathrm{Hg}$ level recorded among all birds was more than five times inferior to this toxicity limit. It can therefore be presumed that the marine birds considered during this work do not suffer from any adverse effects of $\mathrm{Hg}$.

Contrary to $\mathrm{Hg}$, means for renal $\mathrm{Cd}$ were above the $10 \mu g \cdot g^{-1}$ wet weight adverse effects level determined by Eisler (1985). However, Furness (1996) suggested that levels above which adverse effects occur in pelagic seabirds may be higher than for other birds, and that no adverse $\mathrm{Cd}$ effects have been documented in wild seabirds. Cadmium and $\mathrm{Hg}$ levels in soft tissues of adult Barau's Petrels are very close to those found in the squideating Great-winged Petrel (Pterodroma macroptera) from New Zealand. Metal burdens in Audubon's Shearwaters are similar to those found in the piscivorous Cory's Shearwaters from the Azores islands (Stewart et al. 1997a). Although seabirds feeding on similar prey tend to show closer metal burdens than species which diets are different, the geographical origin of the bird is important. For example, the Atlantic Petrel (P. incerta) from Gough Island is very close to the Great-winged Petrel in size and is also a squid-eater. However, its hepatic $\mathrm{Hg}$ (respectively, renal Cd) levels are almost 4 (respectively 2) times higher than those found in the Great-winged Petrel and Barau's Petrel. These comparisons suggest the existence of large differences in elemental levels even among non-industialized, isolated oceanic islands. Besides, these values remain far below levels that can be attained in polluted areas, such as the Saint Lawrence Gulf, where small, $50 \mathrm{~g}$, plankton-eating Leaches Storm Petrels accumulates 3 to 4 times more renal Cd $\left(183 \pm 65 \mu g . g^{-1}\right)$ than the Reunion birds which are larger and feed at a higher trophic level.

\section{Conclusion}

Our study has revealed some similarities and differences which exist between Barau's Petrel, Audubon's Shearwater and the White-tailed Tropicbird in terms of intake and pathways of metabolism and storage of certain elements among age-classes. Diet stood out as a major factor of elemental level variation. Among prey, cephalopods appeared to contribute importantly to the $\mathrm{Cd}$ and $\mathrm{Hg}$ intake of Reunion marine birds. The study of the excretion and storage of $\mathrm{Cd}, \mathrm{Cu}, \mathrm{Fe}, \mathrm{Hg}, \mathrm{Mn}$, Se and $\mathrm{Zn}$ in these three seabirds would be most valuable in order to understand the detoxification strategies employed by these birds. Indeed, Reunion seabirds bioaccumulated fairly high levels of $\mathrm{Cd}, \mathrm{Hg}$, Se and $\mathrm{Zn}$, especially considering the remoteness of Reunion island in respect to anthropic activity. However, for each element, similar or higher levels have been observed in parent species originating from other pristine areas. In this context, two scenarios can be considered: the levels of trace elements measured during this study correspond to (i) backround levels whose sources are natural (volcanism, erosion, etc.), or (ii) the echo of distant pollution which has reached this part of the Wester Indian Ocean by aereal and/or marine currents, or indirectly though the migration of prey species from polluted zones. Physiological studies of the Reunion seabird species would be useful to distinguish healthy birds from those in bad physiological condition in relation to their body condition index (Wenzel and Adelung 1996) in order to better apprehend the influence of the bird's physiological condition on elemental levels. 


\section{Acknowledgments}

This research was supported by the Conseil Général de La Réunion. J.K. also benefited from support of the Conseil Régional de La Réunion and the European Social Fund through a PhD grant. The authors would like to thank E. Robert, M. Rouquette, P. Grondin and N. Ghanem in La Réunion for their help in the tissue preparation and C. Churlaud, Centre Commun d'Analyse (La Rochelle), for her assistance with the analyzes on the ICP-AES. We would also like to thank the numerous volunteers who actively participate in the SEOR Petrel rescue program. We are also grateful towards the referees for their helpful comments on the manuscript.

\section{References}

Ancora S., Volpi V., Olmastroni S., Focardi S., Leonzio C. (2002), Assumption and elimination of trace elements in adélie penguins from antartica: a preliminary study, Mar. Environ. Res. 54: $341-344$.

Bailey R. S. (1967), The pelagic distribution of seabirds in the Western Indian Ocean, Ibis 110: 492-493.

Barré N., Barau A., Jouanin C. (1996), Oiseaux de la Réunion, Les Éditions du Pacifique, Paris.

Bearhop S., Waldreon S., Thompson D., Furness R. (2000), Bioamplification of mercury in Great Skua and Catharacta Skua chicks: the influence of trophic status as determined by stable isotope signatures of blood and feathers, Mar. Poll. Bull. 40(2): 181-185.

Bloom N. S. (1992), A survey of size-specific mercury concentrations in game fish from Maryland fresh and estuarine waters, Arch. Environ. Contam. Toxicol. 39(1): 53-59.

Bocher P., Caurant F., Miramand P., Cherel Y., Bustamante P. (2003), Influence of the diet on the bioaccumulation of heavy metals in zooplankton-eating petrels at Kerguelen archipelago, Southern Indian Ocean, Polar Biol. 26(12): 759-767.

Bolton M., Monaghan P., Houston D. C. (1991), An improved technique for estimating pectoral muscle protein condition from body measurements of live gulls, Ibis 133: 264-270.

Bretagnolle V., Attié C. (1991), Status of Barau's Petrel Pterodroma baraui: colony sites, breeding population and taxonomic affinities, Colonial Waterbirds 14(1): 25-33.

Burger A. E. (2001), Diving depths of shearwaters, Auk 118(3): 755-759.

Burger J. (1993), Metals in feathers of brown noddy (Anous stolidus): Evidence for bioaccumulation or exposure levels?, Environ. Monit. Assess. 24(2): 181-187.

Burger J., Gochfeld M. (1997), Risk, mercury levels, and birds: relating adverse laboratory effects to field biomonitoring, Environ. Res. 75: 160-172.

Burger J., Gochfeld M. (2000), Metal levels in feathers of 12 species of seabirds from Midway Atoll in the northern Pacific Ocean, Sci. Tot. Environ. 257: 37-52.

Bustamante P., Caurant F., Fowler S. W., Miramand P. (1998a), Cephalopods as a vector of the transfer of cadmium to top marine predators in the North-East Atlantic Ocean, Sci. Tot. Environ. 220: 71-80.

Bustamante P., Cherel Y., Caurant F., Miramand P. (1998b), Cadmium, copper and zinc in octopuses from the Kerguelen islands, Southern Indian Ocean, Polar Biol. 19: 264-271. 
Bustamante P., Lahaye V., Durnez C., Churlaud C., Caurant F. (2006), Total and organic Hg concentrations in cephalopods from the North East Atlantic waters: influence of geographical origin and feeding ecology, Sci. Total Environ. 368(2-3): 585-596.

Clarke M. R. (1986), A Handbook for the identification of cephalopod beaks, Sierra Club Books, Oxford.

Debacker V., Jauniaux T., Coignoul F., Bouquegneau J.-M. (2001a), Heavy metal contamination and body condition of wintering Guillemots (Uria aalge) at the Belgian coast from 1993 to 1998, Environ. Res. 84(3): 310-317.

Debacker V., Schiettecatte L.-S., Jauniaux T., Bouquegneau J.-M. (2001b), Influence of age, sex and body condition on zinc, copper, cadmium and metallothioneins in Common Guillemots (Uria aalge) stranded at the Belgian coast, Mar. Environ. Res. 52: 427-444.

Eisler R. (1985), Cadmium hazards to fish, wildlife, and invertebrates: a synoptic review, Technical Report 1.2, U.S. Fish and Wildlife Service.

Eisler R. (1987), Mercury hazards to fish, wildlife, and invertebrates: a synoptic review, Technical Report 1.10, U.S. Fish and Wildlife Service.

Elliott J. E., Scheuhammer A. M., Leighton F. A., Pearce P. A. (1992), Heavy metal and metallothionein concentrations in Atlantic Canadian seabirds, Arch. Environ. Contam. Toxicol. 22(1): $63-73$.

Fiona F. M., Phillips R. A., Bartle A., Craig J., Shooter D. (1999), Influence of phylogeny, diet, moult schedule and sex on heavy metal concentrations in New Zealand Procellariiformes, Mar. Ecol. Prog. Ser. 178: 295-305.

Furness R. W. (1996), Cadmium in birds, in W. N. Beyer, G. H. Heinz, A. W. Redmon-Norwood, eds, Environmental contaminants in wildlife: interpreting tissues concentrations, Lewis Press, Boca Raton, FL, pp. 389-404.

Furness R. W., Greenwood J. J. D., Jarvis P. J., Lehr Brisbin I., Ormerod S. J., Tyler S. J., Montevecchi W. A., Baillie S. R., Crick H. Q. P., Marchant J. H., Peach W. J. (1993), Birds as Monitors of Environmental Changes, Chapman and Hall, Cornwall.

Furness R. W., Rainbow P. S. (1990), Heavy metals in the marine environment, CRC press, Boca Raton, Florida.

Gonzalez-Solis J., Sanpera C., Ruiz X. (2002), Metals and selenium as bioindicators of geographic and trophic segregation in Giant Petrels Macronectes spp., Mar. Ecol. Prog. Ser. 244: 257264.

Gray J. (2002), Biomagnification in marine systems: the perspective of an ecologist, Mar. Poll. Bull. 45: 46-52.

Hindell M. A., Brothers N., Gales R. (1999), Mercury and cadmium concentrations in tissues of three species of southern albatrosses, Polar Biol. 22: 102-108.

Honda K., Marcovecchio J. E., Kan S., Tatsukawa R., Osi H. (1990), Metal concentrations in pelagic seabirds from the north Pacific Ocean, Arch. Environ. Contam. Toxicol 19: 704711.

Jaquemet S., Le Corre M., Weimerskirch H. (2004), Seabird community structure in a coastal tropical environment: importance of natural factors and fish aggregating devices (FADs), Mar. Ecol. Prog. Ser. 268: 281-292. 
Jouanin C. (1963), Un pétrel nouveau de La Réunion Bulweria baraui, Bulletin du Muséum National d'Histoire Naturelle 35: 593-597.

Kim E. Y., Goto R., Tanaka S., Tatsukawa R. (1998), Distribution of 14 elements in tissues and organs of oceanic seabirds, Arch. Environ. Contam. Toxicol. 33: 638-645.

Kim E. Y., Murakami T., Saeki K., Tatsukawa R. (1996a), Mercury levels and its chemical form in tissues and organs of seabirds, Arch. Environ. Contam. Toxicol. 30(2): 259-266.

Le Corre M. (2000), Taxonomic affinities of Audubon's shearwater from Europa Island, Condor 102: $187-190$.

Le Corre M., Ollivier A., Ribes S., Jouventin P. (2001b), Light-induced mortality of petrels: a 4-year study from Reunion Island (Indian Ocean), Biol. Conserv. 105: 93-102.

Monteiro L. R., Costa V., Furness R. W., Santos R. S. (1996), Mercury concentrations in prey fish indicate enhanced bioaccumulation in mesopelagic environments, Mar. Ecol. Prog. Ser. 141: $21-25$.

Monteiro L. R., Furness R. W. (1995), Seabirds as monitors of mercury in the marine environment, Water Air Soil Poll. 80(1-4): 851-870.

Muirhead S. J., Furness R. W. (1988), Heavy metal concentrations in the tissues of seabirds from Gough Island, South Atlantic Ocean, Mar. Poll. Bull. 19(6): 278-283.

Nesis (1987), Cephalopods of the World, T.F.H. Publications, Neptune City, NJ.

Ochoa-Acuna H., Sepulveda M. S., Gross T. S. (2002), Mercury in feathers from chilean birds: influence of location, feeding strategy, and taxonomic effiliation, Mar. Poll. Bull. 44: 340349.

R Development Core Team (2005), R: A language and environment for statistical computing, R Foundation for Statistical Computing, Vienna, Austria.

Smith J. D., Plues L., Heyraud M., Cherry R. D. (1984), Concentrations of the elements Ag, Al, $\mathrm{Ca}, \mathrm{Cd}, \mathrm{Cu}, \mathrm{Fe}, \mathrm{Mg}, \mathrm{Pb}$ and $\mathrm{Zn}$, and the radionuclides 210pb and 210po in the digestive gland of the squid Nototodarus gouldi, Mar. Environ. Res. 68: 13-55.

Stahl J., Bartle J. A. (1991), Distribution, abundance and aspects of the pelagic ecology of Barau's Petrel (Pterodroma baraui) in the south-west Indian Ocean., Notornis 38: 211-225.

Stewart F. M., Monteiro L. R., Furness R. W. (1997a), Heavy metal concentrations in Cory's shearwater, Calonectris diomedea, fledglings from the Azores, Portugal, Bull. Environ. Contam. Toxicol. 58: 115-122.

Stewart F. M., Phillips R. A., Bartle J. A., Craig J., Shooter D. (1999), Influence of phylogeny, diet, moult schedule and sex on heavy metal concentrations in New Zealand Procellariiformes, Mar. Ecol. Prog. Ser. 178: 295-305.

Stewart F. M., Thompson D. R., Furness R. W., Harrison N. (1994), Seasonal variation in heavy metals in tissues of Common Guillemots, Uria aalge from northwest Scotland, Arch. Environ. Contam. Toxicol. 27: 168-175.

Szefer P., Pempkowiak J., Skwarzec B., Bojanowski R., Holm E. (1993), Concentration of selected metals in penguins and other representative fauna of the antartic, Sci. Tot. Environ. 138: 281-288.

Thompson D. R., Furness R. W., Heinz G. H. (1996), Environmental contaminants in wildlife. Interpreting tissue concentrations, Beyer, Heinz and Redmon-Norwood, New York. 
Thompson D. R., Furness R. W., Monteiro (1998), Seabirds as biomonitors of mercury inputs to epipelagic and mesopelagic marine food chains, Sci. Tot. Environ. 213: 299-305.

Walsh P. M. (1990), The use of seabirds as monitors of heavy metals in the marine environment, in R. Furness, P. Rainbow, eds, Heavy metals in the marine environment, CRC Press, Boca Raton, FL, USA, pp. 183-205.

Weimerskirch H. (2001), Seabird demography and its relationship with the marine environnement, in E.A. Schreiber and J. Burger (Eds). Biology of Marine Birds, CRC Press, Boca Raton, Fl., pp. 115-135.

Wenzel C., Adelung D. (1996), The suitability of oiled Guillemots (Uria aalge) as monitoring organisms for geographical comparisons of trace element contaminants, Arch. Environ. Contam. Toxicol. 31: 368-377. 